
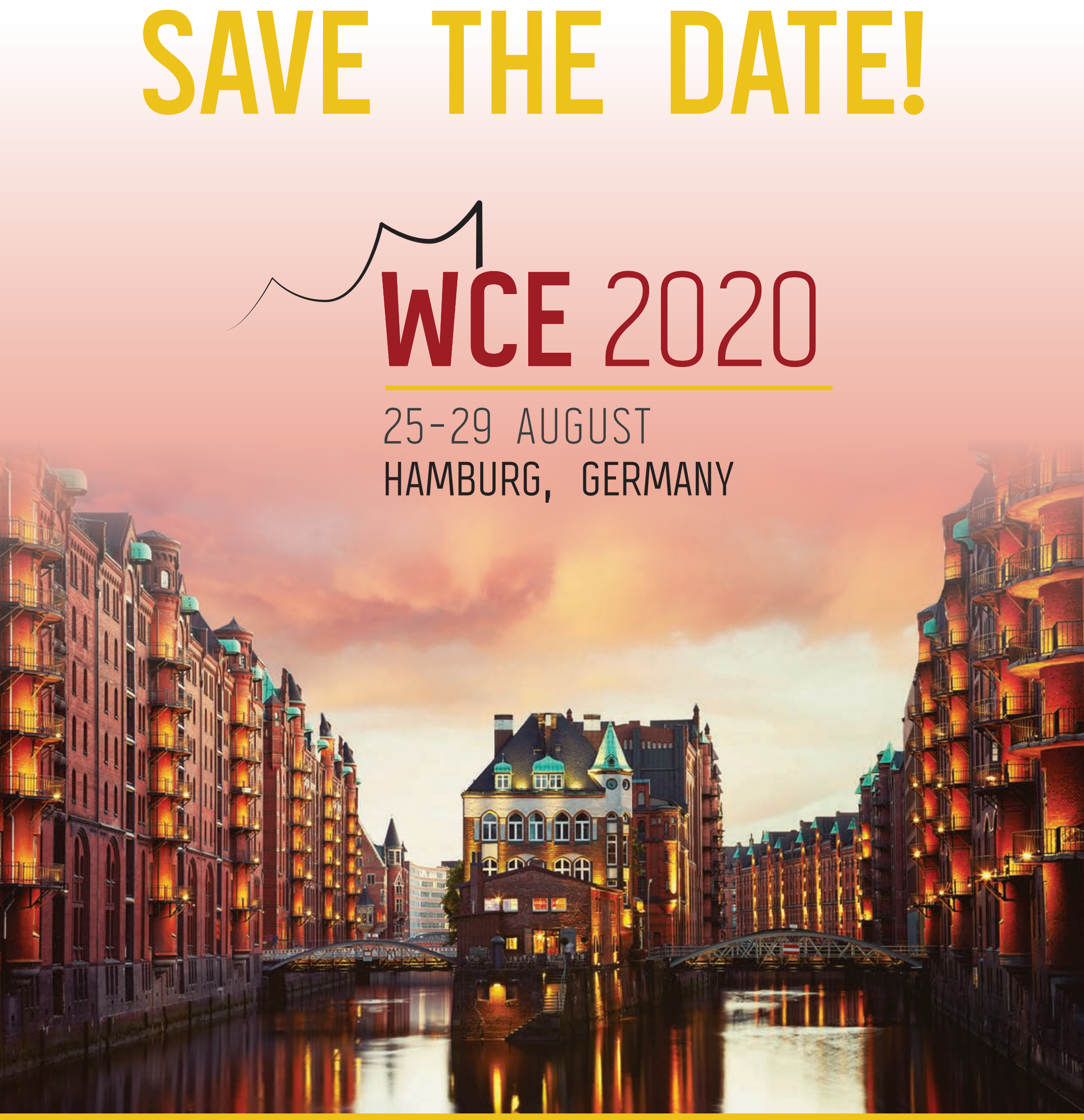

IMPORTANT DATES
January 2020 Registration Opens
February 2020 Abstract Submission Site Opens 


\title{
COMMITTEE MEMBERS
}

\section{EXECUTIVE COMMITTEE OF THE ENDOUROLOGICAL SOCIETY}

\author{
JENS RASSWEILER, MD \\ President \\ ALI RIZA KURAL, MD \\ Past President \\ GLENN PREMINGER, MD \\ President-Elect \\ MARGARET S. PEARLE, MD, PhD \\ Secretary General \\ CHANDRU P. SUNDARAM, MD \\ Treasurer-Elect \\ ADRIAN JOYCE, MD \\ Director of Education \\ BRIAN MATLAGA, MD \\ Associate Director of Education \\ BEN H. CHEW, MD, MSc, FRCSC \\ Research Chair \\ MICHELE PAOLI \\ Executive Director
}




\title{
BOARD OF DIRECTORS
}

\author{
JEFFREY CADEDDU, MD, USA \\ Director \\ NORBERTO O. BERNARDO, MD, Argentina \\ Director \\ JORGE GUITERREZ, MD, USA \\ Member-at-Large \\ JEAN JOSEPH, MD, MBA, FACS, USA \\ Director \\ JIAN HUANG, MD, PhD, China \\ Director \\ ASHOK HEMAL, MD, USA \\ Member-at-Large
}

EVANGELOS LIATSIKOS, MD, PhD, Greece Director

HASSAN RAZVI, MD, Canada Director

ABHAY RANE, MD, United Kingdom Director

ANTHONY C.F. NG, MD, Hong Kong Director

TOMONORI HABUCHI, MD, Japan

Director

GUIDO GIUSTI, MD, Italy

Director

FOUNDING PRESIDENT

ARTHUR D. SMITH, MD

HISTORIAN

STEPHEN Y. NAKADA, MD, FACS

JOURNAL OF ENDOUROLOGY EDITORS

RALPH V. CLAYMAN, MD

ARTHUR D. SMITH, MD

JOHN DENSTEDT, MD 


\title{
SUBGROUP LEADERS
}

BEN CHEW, MD

Chair, CROES (Clinical Research Office of the Endourology Society)

JIHAD KAOUK, MD

\author{
President, SURS (Society of Urological Robotic Surgery) \\ ROBERT SWEET, MD \\ President, Engineering \& Urology Society \\ DIRK LANGE, MD \\ International Society for Urological Stents \\ THOMAS TAILLY, MD \\ Young Endourologists \\ JAMES F. BORIN, MD \\ Image Guided Therapy Working Group
}

\section{WEBSITE COMMITTEE}

Brian D. Duty, MD, Chairman

Khurshid R. Ghani, MD, MS

Athanasios Papatsoris, MD

Michael S. Borofsky, MD

Zhamshid Okhunov, MD

Chandru Sundaram, Treasurer

Brian Matlaga, Associate Director of Education

\section{AWARDS COMMITTEE}

\author{
Eduardo Mazzucchi, MD, Chairman \\ Mordechai Duvdevani, MD \\ Oliver Wiseman, MD, MA, FRCS \\ Benjamin Lee, MD \\ Nicole L. Miller, MD \\ Stephen Y. Nakada, MD, FACS \\ Ali R. Kural, MD \\ Chandru P. Sundaram, MD (Video)
}

\section{FELLOWSHIP COMMITTEE}

Li-Ming $\mathrm{Su}, \mathrm{MD}$, Chairman

Ben H. Chew, MD, MSc, FRCSC

Robert Figenshau, MD

Tom Chi, MD
Guohua Zeng, MD

Mario Sofer, MD

Andreas J. Gross, MD 
FINANCE COMMITTEE

Chandru P. Sundaram, MD, Chair

Benjamin R. Lee, MD

Christopher Netsch, MD

Bodo E. Knudsen, MD, FRCSC

\section{AUA PROGRAM PLANNING COMMITTEE}

Ben Chew, MD, MSc, FRCSC, Chair

Adrian Joyce, MD

Jihad Kaouk, MD

Brian Matlaga, MD

Margaret S. Pearle, MD, PhD

\section{GLOBAL EDUCATION COMMITTEE}

Adrian D. Joyce, MD, Chair

Brian Matlaga, MD

Jihad Kaouk, MD

Evangelos Liatsikos, MD
Bradley Schwartz, MD

Bodo Knudsen, MD

Andreas Gross, MD

Zhamid Okhunov, MD

\section{WORLD ENDOUROLOGY COMMITTEE}

Gopal Badlani, MD, Chair

Raju Thomas, MD, FACS, MHA, MD

Ali R. Kural, MD

Ralph V. Clayman, MD

Marius Conradie, MD

Graham Watson, MD

\section{SOCIAL MEDIA COMMITTEE}

Brian Eisner, MD, Chair

Fabio Vicentini, MD (Lap/Stones)

Fernando Gomez Sancha, MD (BPH)

Matthew Bultitude, MD (Stones)

Riccardo Autorino, MD (Robotics)

John Davis, MD (Robotics)

Igor Sorokin, MD (Stones/Robotics) 


\section{MEMBERSHIP COMMITTEE}

Jaime Landman, MD, Chair

Ali R. Kural, MD

Joseph Wang, MD

Abbas Basiri, MD

Joel Aldana, MD

Alex E. Meller, MD

Zhamshid H. Okhunov, MD

\section{Delegates}

Damien Bolton, MD

Eduardo Mazzucchi, MD

Alex Meller

Kenneth T. Pace, MD, MSc, FRCSC

Guohua Zeng, MD

Kunjie Wang, MD, PhD

Anthony C.F. Ng, MD

Thomas Knoll, MD, PhD, MSc

Joseph Wong

Shahikant Mishra, MD

Nasser Simforoosh, MD

Mordechai Duvdevani, MD

Salvatore Micali, MD

Tomonori Habuchi, MD

Hiroomi Kanayama, MD, PhD

Sanzkar Shalerenov

Koon H. Rha, MD

Daniel Olvera-Posada

Jose Benito Abraham, MD

Alexeiy G. Martov, MD, PhD

Mohammed Alomar

Burak Turna, MD

Ömer Tuncay

Sergei Shamraev, MD

Yasser Farahat

Oliver Wiseman, MD, MA, FRCS

Jean Joseph, MD, MBA, FACS

Bodo E. Knudsen, MD, FRCSC

Nicole L. Miller, MD

Shukhrat Mukhtarov

Australia
Brazil
Brazil
Canada
China
China
China
Germany
Hong Kong
India
Iran
Israel
Italy
Japan
Japan
Kazakhstan
Korea
Mexico
Philippines
Russia
Saudi Arabia
Turkey
Turkey
Ukraine
UAE
United Kingdom
United States
United States
United States
Uzbekistan

\section{TH WORLD CONGRESS OF ENDOUROLOGY ORGANIZING COMMITTEE}

Olivier Traxer, MD - President of WCE 2019

Eric Barret, MD

Alexandre de la Taille, MD

Eric Lechevallier, MD

Christian Saussine, MD

Steeve Doizi, MD

Andras Hoznek, MD
Franck Bruyère, MD

Alaa El Ghoneimi, MD

Karim Bensallah, MD

Benjamin Pradère, MD

Michel Daudon, MD

Jean-Philippe Haymann, MD

Morgan Roupret, MD 


\section{RECIPIENT OF THE KARL STORZ "LIFETIME ACHIEVEMENT" AWARD}

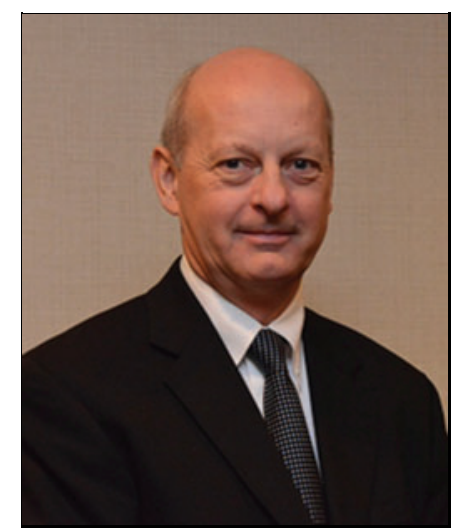

John D. Denstedt, MD, FRCSC, FACS, FCAHS

Dr. John Denstedt graduated from medical school in 1982 at The University of Western Ontario in London, Canada. He completed his residency in urology at Western between 1983 and 1987, followed by a fellowship in endourology at Washington University in St. Louis. He returned to London and joined the Division of Urology in the Department of Surgery at Western in 1990.

In July 2002 he assumed the role of city-wide chair and chief of the Department of Surgery at Western University and served in this role for 14 years. Dr. Denstedt is a past chair of the Canadian Association of Surgical Chairs and a past member of the American Urological Association Board of Directors. He completed a 10-year term as treasurer of the Endourological Society in 2018.

While maintaining an active clinical practice, Dr. Denstedt is an internationally renowned scholar in urology with career accomplishments encompassing over 250 published papers and book chapters, more than 300 guest professorships in countries throughout the world, and numerous honors and awards including being the first Canadian to have won the Gold Cystoscope Award from the American Urological Association in 1998. Dr. Denstedt serves on the editorial board of eight major journals in urology and is currently executive editor of the Journal of Endourology. He is currently the secretary elect of the American Urological Association and will assume a 4-year term as secretary in 2019. 


\section{RECIPIENT OF THE RALPH CLAYMAN "MENTOR" AWARD}

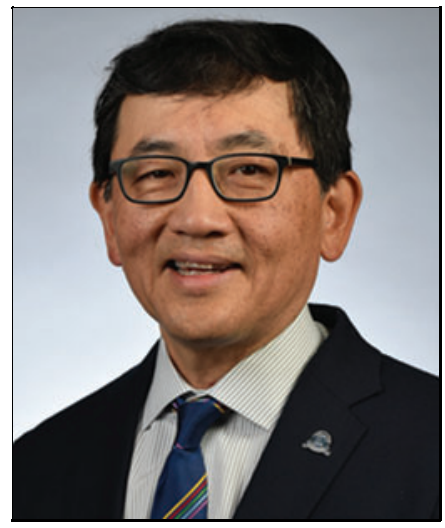

Stephen Y. Nakada, MD, FACS, FRCS (Glasg)

Stephen Y. Nakada, MD, FACS, FRCS (Glasg) is Professor and Chairman of the Department of Urology and the David T. Uehling Chair of Urology at the University of Wisconsin School of Medicine and Public Health in Madison, WI. He received his medical degree from the University of Rochester School of Medicine and Dentistry and completed his residency training at Strong Memorial Hospital in Rochester, NY. Dr. Nakada went on to complete his endourology fellowship at Washington University prior to joining the faculty at the University of Wisconsin in 1995. Dr. Nakada has been the chairman of urology in Madison since 2001.

Dr. Nakada's research focuses on urolithiasis and renal aspects of minimally invasive urology. He has authored or coauthored over 250 scientific articles and 50 book chapters, and he has edited more than 10 textbooks in those areas. In 2004, Dr. Nakada received the Gold Cystoscope Award from the American Urological Association (AUA) and in 2017 the AUA Distinguished Service Award. He is currently an editorial consultant for Urology Times and an assistant editor of the Journal of Endourology.

Dr. Nakada has served as president of the R.O.C.K. Society, the Society of Academic Urologists, the Endourological Society, and the American Board of Urology. He has served on the AUA Staghorn Stone and Ureteral Stones Guidelines Committees, the AUA/ABU Examination Committee, and he served as the chair of the AUA Laparoscopy and Robotic Surgery Committee. Currently Dr. Nakada is a member of the Advisory Council in Urology to the American College of Surgeons. Dr. Nakada is an active member of the American Association of Genitourinary Surgeons, and the Clinical Society of Genitourinary Surgeons, among other societies. 


\section{RECIPIENT OF THE "ARTHUR" AWARD}

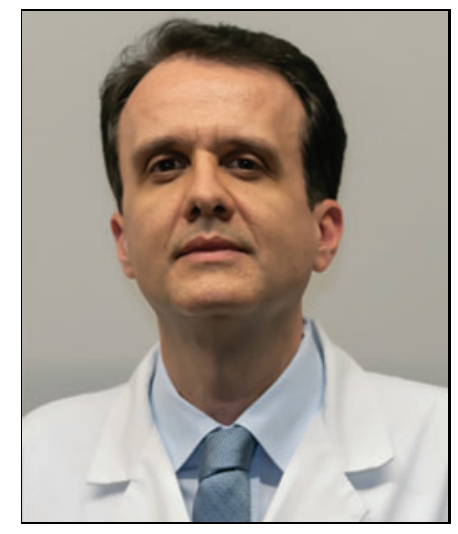

Athanasios (Thanos) Papatsoris

Professor Athanasios (Thanos) Papatsoris graduated from Patras University School of Medicine with an honorary scholarship and obtained a MSc in benign prostatic hyperplasia (BPH). His PhD in bladder cancer was conferred by the Athens School of Medicine. He trained in urology in Athens and London, where he also completed a 2-year endourology fellowship (SpR level at Barts Hospital) officially recognized by the Endourological Society. He then completed a clinical fellowship in laparoscopy in Le Mans, France, supported by the European University at Saint Petersburg (EUSP). Furthermore, he served one year as an honorary consultant in Urology at Royal London Hospital, Barts Health NHS Trust. He holds honorary contracts at Addenbrooke's Hospital, Cambridge and Imperial London Healthcare NHS Trust. He obtained his FEBU degree in 2007 and since then has been an FEBU examiner, while also serving as vice chairman of the European Board of Urology (EBU) Examination Committee for the last years.

Since 2017, Dr. Papatsoris is an associate professor in urology at the Second Department of Urology, School of Medicine, Sismanoglio General Hospital, Athens, Greece. Moreover, he is an associate board member of ESUT (Endourology Section), EULIS, ESOU (Prostate Cancer Committee), SEGUR, and U-Merge. He is the EBU, UEMS, and SIU National Delegate as well as uCARE SIU Board member (head of the Publication and Communication Committee) and SIU Academy Endourology Board member. For 4 years he served as the secretary (assistant/general) of HUA and the vice chairman of the HUA Section of Endourology - Laparoscopic Surgery and Urotechnology. Furthermore, he is a board member of IMIBE as well as the secretary general of HGUCG and member of the Endourological Society Website Committee.

Prof. Papatsoris Hirsch index is 26 and he has more than 170 publications in PubMed indexed journals with more than 2000 citations; 90 endourology-related as first or senior author (original papers, reviews, points of surgical techniques). He participated in the development of the endoscopic stone treatment step 1 training/assessment curriculum and serves as the principal investigator in several studies. Lastly, Prof. Papatsoris is a member of the editorial board of several journals, and he has been invited as faculty in international congresses, workshops, HOT, intensive courses, mentoring, and live surgeries in endourology. 


\section{RECIPIENT OF THE ENDOUROLOGY SOCIETY "INDUSTRY" AWARD}

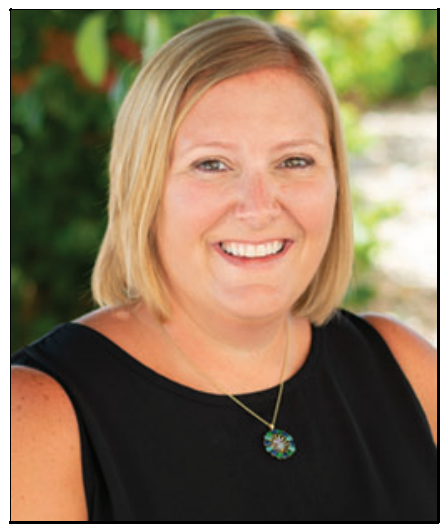

Shayna Martin

As the global brand marketing director for Cook Medical's urology business, Shayna Martin has more than 15 years of experience in healthcare marketing. She started her healthcare marketing career at an Indiana-based agency where she focused on hospital marketing across a variety medical specialties and healthcare insurance companies throughout the United States. This role laid the groundwork that she continues to build on as she expands her understanding of the global healthcare community.

Ms. Martin started her career with Cook Medical as a brand marketing specialist in 2010. After a short stint with Indiana University in 2011, Ms. Martin returned to Cook to serve as the global brand marketing manager for the urology specialty and was later promoted to director in 2016. Ms. Martin is passionate about continuing Cook's long-standing goal of partnering with physicians to continue to improve healthcare through innovation, collaboration, and education. Her ability to develop, foster, and strengthen relationships has helped her succeed in her role today.

Ms. Martin graduated with a Bachelor of Arts in Journalism from Indiana University in Bloomington, Indiana, where she currently resides. 